\title{
PROOXIDANT ACTIVITIES OF ANTIOXIDANTS AND THEIR IMPACT ON HEALTH
}

\author{
Robert Sotler ${ }^{1}$, Borut Poljšak ${ }^{2}$, Raja Dahmane ${ }^{3}$,Tomislav Jukić ${ }^{4}$, Doroteja Pavan Jukić ${ }^{5}$, \\ Cecilija Rotim ${ }^{6}$, Polonca Trebše ${ }^{3}$ and Andrej Starc ${ }^{7}$
}

\author{
${ }^{1}$ Faculty of Health Sciences, University of Ljubljana, Department of Nursing, Ljubljana, Slovenia; \\ ${ }^{2}$ Faculty of Health Sciences, University of Ljubljana, Department of Health Ecology and Control, \\ Ljubljana, Slovenia; \\ ${ }^{3}$ Faculty of Health Sciences, University of Ljubljana, Department of Biomedicine in Health Care, \\ Ljubljana, Slovenia; \\ ${ }^{4}$ Faculty of Medicine, Josip Juraj Strossmayer University of Osijek, Department of Internal Medicine, \\ Family Medicine and History of Medicine, Osijek, Croatia; \\ ${ }^{5}$ Faculty of Medicine, Josip Juraj Strossmayer University of Osijek, \\ Department of Gynecology and Obstetrics, Osijek, Croatia; \\ ${ }^{6}$ Dr Andrija Štampar Teaching Institute of Public Health, Zagreb, Croatia; \\ ${ }^{7}$ Faculty of Health Sciences, University of Ljubljana, Department of Public Health, Ljubljana, Slovenia
}

SUMMARY - This review article is focused on the impact of antioxidants and prooxidants on health with emphasis on the type of antioxidants that should be taken. Medical researchers suggest that diet may be the solution for the control of chronic diseases such as cardiovascular complications, hypertension, diabetes mellitus, and different cancers. In this survey, we found scientific evidence that the use of antioxidants should be limited only to the cases where oxidative stress has been identified. This is often the case of specific population groups such as postmenopausal women, the elderly, infants, workers exposed to environmental pollutants, and the obese. Before starting any supplementation, it is necessary to measure oxidative stress and to identify and eliminate the possible sources of free radicals and thus increased oxidative stress.

Key words: Oxidative stress; Antioxidants; Diet; Chronic disease; Dietary supplements; Free radicals

\section{Introduction}

Today, the world is witnessing an upsurge in chronic diseases such as cardiovascular complications, hypertension, diabetes mellitus, and different cancers. Medical researchers suggest that diet may be the solution for the control of these chronic diseases. Diets rich in fruits and vegetables have been reported to have a protective effect against cardiovascular disease and

Correspondence to: Asst. Prof. Andrej Starc, PhD, Faculty of Health Sciences, University of Ljubljana, Chair of Public Health, Zdravstvena pot 5,1000 Ljubljana, Slovenia

E-mail: andrej.starc@guest.arnes.si

Received December 4, 2017, accepted December 5, 2018 cancer ${ }^{1-4}$. The nutrients thought to provide protection by fruits and vegetables are antioxidants ${ }^{5,6}$. Oxidative stress is the basic etiology of disease and can be viewed as an imbalance between antioxidants and prooxidants in the body. Antioxidants that can react with molecular oxygen and are reducing agents can act as prooxidants. Under aerobic conditions, they generate superoxide radicals and dismutate to $\mathrm{H}_{2} \mathrm{O}_{2}$, which reacts with reduced metal ions and superoxide to form toxic reactive oxygen species (ROS). For example, flavonoids can react as prooxidants when a reduced metal is available, and tocopherols can also act as prooxidants when transition metals such as $\mathrm{Cu}(\mathrm{I})$ are present, but this depends on the matrix environment in which it is 
present. It might not always be beneficial to increase cellular viability with a high dose of antioxidants such as beta-carotene or vitamin $\mathrm{E}$ prior to toxic compound-induced exposure (ionizing radiation, UV radiation, cigarette smoke). ROS scavengers, such as ascorbic acid, can act in oxidation-reduction reactions both as prooxidants and antioxidants, depending on the conditions ${ }^{7-10}$.

The question is whether decreasing damage with antioxidants may boost the occurrence of neoplasia by permitting genetically damaged cells to survive. The research by Halliwell and Gutteridge ${ }^{11}$ confirmed this hypothesis. After vitamin supplementation, the subject mortality rate increased, which was probably the result of the antioxidant effect on cell proliferation ${ }^{9,10}$. Malignancy may be enhanced under the antioxidant activity that encourages survival of precursor tumor cells in altered matrix environments.

In spite of the high number of antioxidant studies provided by Pubmed, it is still not clear if the antioxidant supplementation is beneficial or harmful, especially for the healthy well-nourished populations. The goal of this article is to review the impact of antioxidants and prooxidants on health and find the answer to the question: should supplements of antioxidants be taken?

\section{Natural Antioxidants}

Halliwell and Gutteridge ${ }^{11}$ defined antioxidants as "any substance that delays, prevents or removes oxidative damage to a target molecule". Others defined them as "any substance that directly scavenges ROS or indirectly acts to up-regulate antioxidant defenses or inhibits ROS production". The antioxidant activity is effective through different ways, i.e. by interrupting propagation of the auto-oxidation chain reaction; as inhibitors of free radical oxidation reaction; as inhibitors of prooxidative enzymes; as reducing agents that convert hydroperoxides into stable compounds; as metal chelators that convert iron and copper (metal prooxidants) into stable products; and as singlet oxygen quenchers ${ }^{10,12,13}$. It seems likely that, in vivo, the activation of enzymatic antioxidant defenses is more important than radical scavenging ${ }^{14}$ by exogenous antioxidants ingested from the food.

Endogenous antioxidative cell defenses include a network of enzymatic and non-enzymatic molecules

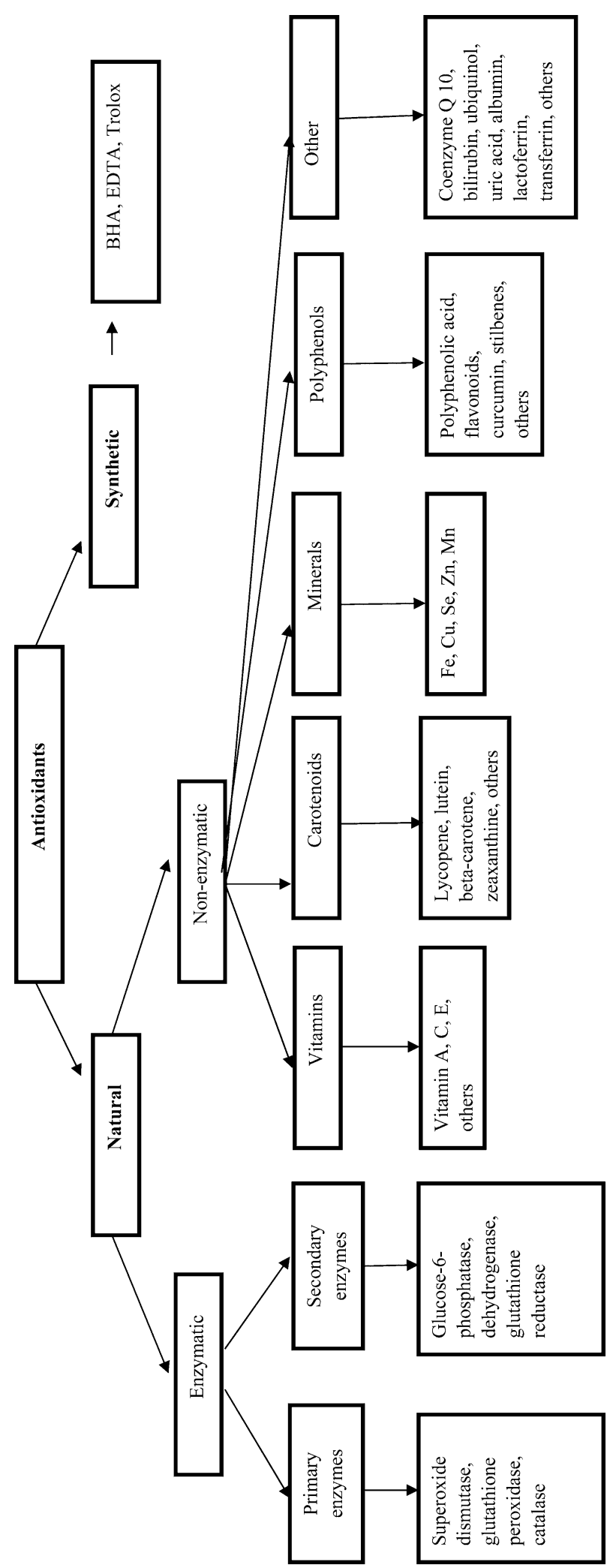

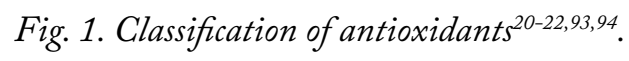


that are distributed within the cytoplasm and cell organelles (Fig. 1). The enzymatic antioxidants are divided into primary and secondary enzymatic defenses. The primary antioxidant enzymes, such as superoxide dismutase (SOD), several peroxidases and catalase, catalyze a cascade of reactions to convert ROS to more stable molecules such as $\mathrm{H}_{2} \mathrm{O}$ and $\mathrm{O}_{2}$. One molecule of catalase can convert 6 billion molecules of hydrogen peroxide. Superoxide dismutase catalyzes dismutation of superoxide anion $\left(\mathrm{O}^{-}\right)$to $\mathrm{H}_{2} \mathrm{O}_{2}$ and $\mathrm{O}_{2}$. The rate of this enzymatic dismutation is approximately 10000 times greater than the spontaneous rate ${ }^{15}$. SOD converts superoxide anions into hydrogen peroxide as a substrate for catalase ${ }^{16}$.

Besides primary enzymes, a large number of secondary enzymes (glutathione reductase and glucose6-phosphate dehydrogenase) do not neutralize ROS directly, but act in association with other endogenous antioxidants. Glutathione reductase reduces glutathione and recycles it to neutralize even more ROS. Glucose-6-phosphate dehydrogenase regenerates nicotinamide adenine dinucleotide phosphate (NADPH) creating a reducing condition ${ }^{17}$.

There are quite a number of non-enzymatic endogenous antioxidants. Cofactor as coenzyme $\mathrm{Q}_{40}$ is present in cells and membranes and plays an important role in cellular metabolism and in the respiratory chain. Turunen et al. ${ }^{17}$ report that this coenzyme $\mathrm{Q}_{40}$ neutralizes the lipid peroxyl radicals and regenerates vitamin E. Vitamin A (retinol) is produced by the liver. There are different forms of vitamin A; their antioxidant effect is the ability to combine with peroxyl radicals before they propagate peroxidation to lipids ${ }^{18}$. Uric acid is a nitrogen non-protein compound that has an important function within the body (after undergoing renal filtration, $90 \%$ of it is reabsorbed). It prevents the lysis of erythrocytes and is an important scavenger of singlet oxygen ${ }^{19}$.

Small molecular-weight non-enzymatic antioxidants, i.e. glutathione, vitamins $\mathrm{E}$ and $\mathrm{C}$, minerals such selenium, and NADPH act as scavengers of ROS. Glutathione is an organosulfur compound, which besides protecting cells against radicals, regenerates vita$\min \mathrm{C}$.

Vitamin C (ascorbic acid) is the major hydrophilic antioxidant and a powerful inhibitor of lipid peroxidation. It can scavenge the reactive nitrogen oxide, superoxide radical anion, hydroxyl radical and singlet oxy- gen $^{20}$, and promotes the regeneration of alpha-tocopherol.

Vitamin $\mathrm{E}$ is composed of four isoforms of tocopherols and four isoforms of tocotrienols. Alpha tocopherol is the most abundant and potent; it halts lipid peroxidation and then protects the lipid structure of cell membranes; it is thought to prevent atherosclerosis ${ }^{21}$. Selenium and zinc are found in trace quantities but play an important role in animal and human metabolism. Selenium does not act directly on ROS but is an important part of the antioxidant enzymes (e.g., glutathione peroxidase $)^{22}$. Just like selenium, zinc does not attack ROS directly, but prevents their formation ${ }^{23}$.

Flavonoids are natural food-derived components (fruits, vegetables and herbs) that have received great attention in the last decades. They are composed of flavonols, flavanols, anthocyanins, isoflavonoids, flavonones and flavones. All these categories share the same diphenylpropane skeleton. The most abundant flavonol is quercetin; it prevents oxidative stress and cell death by scavenging ROS, chelating metal ions and quenching singlet oxygen ${ }^{24}$. The most abundant flavanol is catechin present in red wines ${ }^{25}$; it has an important antioxidant, anti-inflammatory effect and estrogenic growth-promoting effect ${ }^{26}$.

Phenolic acids are divided in two groups, hydroxycinnamic (ferulic acid, p-coumaric) and hydroxybenzoic acids (gallic and ellagic acid). They act as chelators and ROS scavengers with special effect on hydroxyl and peroxyl radicals. The most promising compound is gallic acid (precursor of tannins) ${ }^{27}$.

\section{Synthetic Antioxidants}

Synthetic antioxidants are added to the food so it can withstand different treatments. Their focus is to prevent food oxidation, especially fatty acids. Today, almost all processed foods have synthetic antioxidants incorporated and are reported to be safe, although some studies indicate otherwise ${ }^{28}$. Butylated hydroxytoluene (BHT) and butylated hydroxyanizole (BHA) are the most widely used synthetic antioxidants. The European food safety authority ${ }^{29}$ has established revised acceptable daily intakes (ADIs) of $0.25 \mathrm{mg} / \mathrm{kg}$ $\mathrm{bw} /$ day for BHT and $1.0 \mathrm{mg} / \mathrm{kg}$ bw/day for BHA. Octyl gallate (OG) seems to be safe to use because it is hydrolyzed after ingestion into gallic acid and octanol, which are present in plants ${ }^{2}$. 


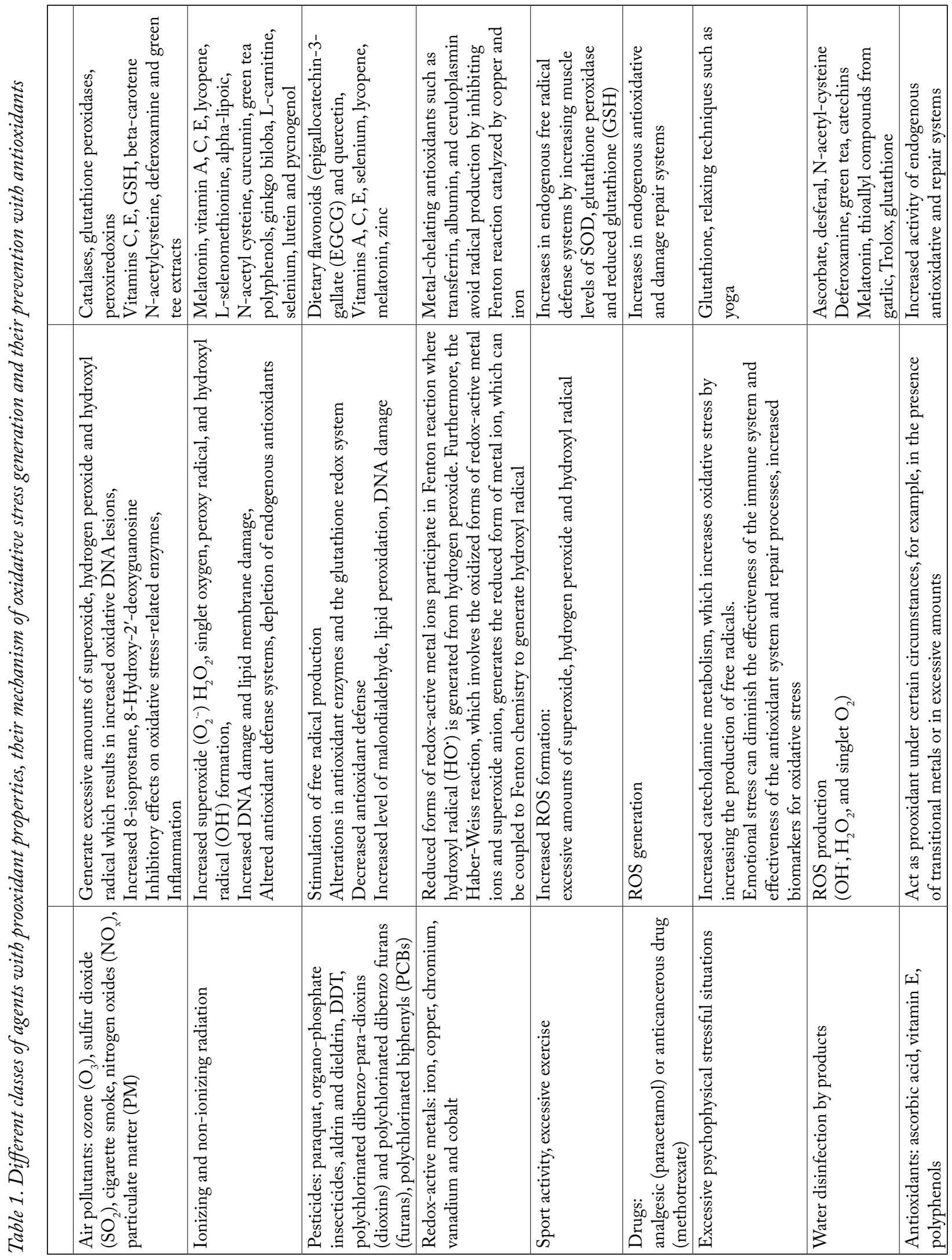




\section{Prooxidants}

Prooxidants are defined as chemicals that induce oxidative stress, through formation of ROS or by inhibiting the antioxidant system. They may be classified into several categories (Table 1), as follows: drugs, redox-active metals, pesticides, physical exercise, mental anxiety, pathophysiological conditions, environmental factors (air pollutants and ionizing and non-ionizing radiation), water disinfection products, and antioxidants $^{30}$.

Drugs such as analgesic (paracetamol) or anticancerous (methotrexate) agents generate ROS and alter macromolecules, which can finally damage liver and kidney tissues. Redox-active metals such as iron and copper can induce Fenton reaction and Haber-Weiss reaction leading to excessive formation of ROS. For example, hematochromatosis is a prooxidant disease due to high iron level, and Wilson disease results in copper overload in the liver and brain ${ }^{31-33}$. Pesticides such as DDT stimulate ROS generation, induction of lipid peroxidation, and alteration of the antioxidant enzymes and glutathione redox system. Rigorous physical exercise such as running and weight lifting generates the production of ROS because of muscle contraction and increased oxygen consumption. Mental anxiety and apprehension induce imbalance in the redox system and lead to neuro-inflammation, neurodegeneration, inhibition of neurogenesis and mitochondrial dysfunction. Local ischemia also increases ROS generation. Environmental factors and adaptation to extreme weather disrupt the mitochondrial membrane fluidity and transfer of electrons leading to ROS generation. Vitamins $\mathrm{C}$ and $\mathrm{E}$ or polyphenols can act as prooxidants under certain conditions ${ }^{7,9,11,28,30-34}$.

\section{Prooxidant Activities of Antioxidants}

Surprisingly, some popular antioxidants have been reported to have prooxidant behavior. At least three factors can influence the function of an antioxidant transforming it to a prooxidant; these factors include the presence of metal ions, the concentration of the antioxidant in matrix environments and its redox potential $^{35-37}$.

Vitamin $\mathrm{C}$ is a potent antioxidant but it can intervene as a prooxidant depending on the dose. It can have an antioxidant effect in case of low dose (30-100 $\mathrm{mg} / \mathrm{kg}$ body weight) and prooxidant effect in case of high dose $(1000 \mathrm{mg} / \mathrm{kg} \text { body weight })^{38}$. The prooxidant effect of vitamin $\mathrm{C}$ also occurs when it combines with iron, reducing $\mathrm{Fe}^{3+}$ to $\mathrm{Fe}^{2+}$ or with copper reducing it from $\mathrm{Cu}^{2+}$ to $\mathrm{Cu}^{+39,40}$. The reduced transition metals in turn reduce hydrogen peroxide to hydroxyl radicals through Fenton reaction ${ }^{41,42}$. The supplementation of vitamin $\mathrm{C}$ and trolox (water-soluble analog of vitamin E) may result in lower normal biological response to free radicals and create an environment that is more sensitive to oxidation. These antioxidants might provoke mild oxidative stress due to their prooxidative properties ${ }^{43}$.

Alpha-tocopherol is also known as a potent antioxidant and harmful prooxidant in high concentrations. When reacting with $\mathrm{ROS}$, it becomes a radical itself, and if there is not enough vitamin $\mathrm{C}$ for its regeneration, it remains in the reactive state ${ }^{8,9}$.

The prooxidant activity of beta-carotene depends on its interaction with biological membranes and the presence of co-antioxidants such as vitamin C. At higher oxygen tension, beta-carotene loses its effectiveness as antioxidant. A systematic review and metaanalysis revealed increased mortality rates after prolonged use of supplements with beta-carotene, vitamin $\mathrm{A}$ and vitamin $\mathrm{E}^{44}$.

Even flavonoids have been reported to act as prooxidants in the systems that contain transition metals ${ }^{7}$. Flavonoids, such as quercetin and kaempferol, induce DNA damage and lipid peroxidation in the presence of the transition metal.

Phenolics can also display prooxidant effects, especially in a system containing redox-active metals. The presence of iron or copper catalyzes their redox cycling and may lead to the formation of phenolic radicals which damage lipids and DNA ${ }^{45,46}$.

\section{Should Supplements of Antioxidants Be Taken?}

\section{Diseases that have positive correlation to oxidative stress}

The oxidative stress of biological systems is defined as the harmful effect of ROS causing biological damage. It is evident when there is an excessive production of ROS or a deficiency of enzymatic and non-enzymatic antioxidants ${ }^{47-51}$. 
The most sensitive organ to ROS damage is the brain because of the low total antioxidant capacity, high consumption of total body oxygen (20\%), high levels of polyunsaturated fatty acids, and low levels of iron-binding proteins (ferritin). These characteristics associate neurodegenerative diseases (Alzheimer's and Parkinson's diseases) with oxidative stress ${ }^{52,53}$.

The relationship between oxidative stress and immune function of the body is well established. Oxidative stress can induce production of free radicals that can modify proteins. Alterations in self-antigens (modified proteins) can instigate the process of autoimmune diseases. There are different examples of autoimmune diseases resulting from oxidative damage to self-proteins, namely, systemic lupus erythematosus (60 kD Ro ribonucleoprotein $)^{54}$ and diabetes mellitus (high molecular weight complexes of glutamic acid decarboxylase $)^{55}$.

Beatty et al. ${ }^{56}$ demonstrated the role of oxidative stress in the pathogenesis of age-related macular degeneration. Oxidative stress is also reported to be the cause of induction of allergies; it has been revealed that reduced NADPH oxidase is present in pollen grains and can lead to induction of airway associated oxidative stress. Such oxidative damage is responsible for developing allergic inflammation in sensitized animals.

Different research studies demonstrated the neoplastic effect of persistent oxidative stress. Oxidative stress due to altered inflammation acts as a precancerous state of host cells leading to the initiation of genetic mutations, genetic errors, epigenetic abnormalities, wrongly coded genome, and impaired regulation of gene expression ${ }^{49,57}$.

According to multiple studies ${ }^{58-61}$, oxidative stress is also linked to atherosclerosis (because of the reduced NADPH oxidase system), glomerular nephropathy (because of glutathione transferase kappa deficiency) and osteoarthritis (radical oxygen species). Filippo et $a l^{62}$ claim that oxidative stress is the leading cause of acute myocardial infarction in diabetics.

\section{Effect of antioxidants on health and disease}

In the last decades, antioxidants have been extensively studied ${ }^{9,10,12,13}$ and proposed as supplementation in reducing the incidence of cancer and ischemic vascular disease ${ }^{63,64}$. Unfortunately, the value of antioxidant strategies seems debatable since supplementation studies showed unreliable and ambiguous outcomes. According to the National Institutes of Health ${ }^{65}$, most of the data examined on using antioxidants fail to give reliable evidence as to beneficial effects on health when the supplements are taken either singly, in pairs, or in combinations of three or more.

The controversy around dietary antioxidants is due to their capacity to act as prooxidants depending on their concentration and the nature of surrounding molecules ${ }^{66}$. Schafer ${ }^{67}$ confirmed this hypothesis in his study, which revealed an unexpected mechanism of cell survival in unnatural matrix environments by antioxidant restoration, which might be disrupted with supplementation of only one antioxidant leading to alteration of the apoptosis reaction. Additionally, ingestion of synthetic antioxidants can lower the synthesis of endogenous antioxidants, as reported in subjects performing sports activity. For example, antioxidant therapy (using different synthetic antioxidants such as vitamins $\mathrm{A}, \mathrm{C}, \mathrm{E}$, and resveratrol) can even prevent the beneficial effects obtained with regular exercise, most probably due to the reduced mitochondrial biogenesis, which is stimulated by excessive ROS formation. Additionally, the imbalance caused by reducing ROS and/ or increasing the antioxidant capacity affects cellular signaling and thus could mitigate the training benefits $^{68,69}$.

Antioxidants may thus have contradictory influence on cancer development; they can prevent oxidative stress to DNA and then stop tumorigenesis; they also can allow survival of damaged cells and then promote tumorigenesis ${ }^{70,71}$. The research by Chen and Guarente $^{72}$ demonstrated correlation between metastasis of breast cancer cells to the brain and enhanced pentose phosphate pathway flux with an increased antioxidant capacity.

Antioxidants also failed to provide satisfying protection to the brain because of the blood brain barri$\mathrm{er}^{73}$. Some authors found resveratrol to be identified as a natural therapeutic agent with pharmacological potential against a wide range of neurodegenerative diseases including Alzheimer's disease, Parkinson's disease, Huntington's disease, amyotrophic lateral sclerosis and alcohol-induced neurodegenerative disorder ${ }^{74}$. It was found ${ }^{75}$ that in vitro polymerization of the $\beta$-amyloid peptide was markedly inhibited by resveratrol, which stimulates the proteosomal degradation of the $\beta$-amyloid peptides ${ }^{76}$. A limitation regarding the 
results of this research is that cell cultures, which react to antioxidants in vitro, are leading to erroneous interpretation and are usually overlooked by peer-review. Direct investigation of oxidative damage ramifications and prooxidant effect on humans due to their molecular and physiological complexity is of outmost importance.

Findings from rodents and worms to humans should be approached with caution. Laboratory mice are more sensitive to dietary antioxidants than humans.

Different routes of antioxidant administration may cause different metabolic interactions; for example, the per os route can be neutralized during transit to the intestine, where the liver sequestrates some amounts, so that the bioavailability of the original antioxidant for other tissues is reduced (reduced glutathione). Flavonoids are markedly biotransformed by intestinal microorganisms and therefore aglycone bioflavonoids, which are frequently introduced in many promising in vitro research studies, pass through the intestinal absorption barrier and enter the bloodstream at a defined molar concentration range $\mathrm{e}^{77,78}$.

The amount of daily intake of synthetic antioxidants presents another major limitation. Some scientists and pharmacological companies suggest consuming larger amounts of antioxidants to effectively fight oxidative stress. It should be emphasized that the recommended daily intake (RDA) values of vitamins should not be exceeded, although there have been arguments that RDA levels are too low ${ }^{79}$.

In the Cochrane systematic reviews on antioxidants and all cause mortality, there was no evidence to support antioxidant supplements for primary or secondary prevention. Beta-carotene and vitamin $\mathrm{E}$ seem to increase mortality, and so may higher doses of vitamin A. Antioxidant supplements need to be considered as medicinal products and should undergo sufficient evaluation before marketing ${ }^{79}$.

\section{Does antioxidant supplementation make sense?}

The contemporary human population presents an increase in the senior fraction of people $(65$ years and older) that have an importance from the health point of view. Because of this demographic fact, nutrition and dietary supplementation with antioxidants has become very popular. Nevertheless, until now, no clinical studies and treatment with synthetic antioxidants have been able to produce significant desired results ${ }^{79-81}$. Selman et al. ${ }^{82}$ proposed some possible explanations for the inability of antioxidants to ensure longevity in animals and to reduce the incidence of disease in humans. In vivo, some antioxidants may act more as prooxidants than antioxidants as they possibly constrain higher activation of the defense system to keep the status quo ${ }^{83}$. The knowledge of the mechanisms of bioavailability, biotransformation, and interaction of antioxidant supplements is yet insufficient.

However, the use of antioxidant supplements should be limited only to the cases in which oxidative stress is well documented. Before starting any supplementation, it is necessary to measure oxidative stress and to identify and eliminate the possible sources of free radicals and thus increased oxidative stress. The institutionalized seniors often show signs of malnutrition; previous research shows that the elderly are at a particular risk due to deficiency of vitamins $\left(B_{12}\right.$ and D) and trace elements ${ }^{84}$. They can even increase their need for nutrient intake because of changes in the absorptive and metabolic capacity. For vulnerable groups, different supplements such as folic acid for women of childbearing age, iron supplements for women with heavy menstrual flow, vitamin D for young children, pregnant women and older (housebound) people are recommended. Moreover, magnesium could be useful in the management of hypertensive heart disease ${ }^{85}, \mathrm{Al}-$ zheimer's $^{86}$ and osteoporosis ${ }^{87}$. Omega-3 fatty acids presumably lower the risk of cardiovascular disease ${ }^{88}$ and cancer ${ }^{89}$. Garlic extracts fight viral and bacterial infections and prevent chronic inflammation ${ }^{90}$.

People who consume fruits and vegetables, which are a rich source of antioxidants, are at a lower risk of cardiovascular and some neurological diseases ${ }^{91}$. Evidence shows that some varieties of vegetables and all kinds of fruit have anticarcinogenic properties. This indicates that some other substances in fruits and vegetables (flavonoids), or a mixture of substances (synergism) might add to the improved cardiovascular health and decreased cancer incidence, as it was observed in the individuals consuming more of such foods ${ }^{92}$.

\section{Discussion}

The most recent epidemiological data on the treatment with synthetic antioxidants indicate that the results were ambiguous and even misleading; they were 
found to be toxic, neutral, and even beneficial. It was only scientifically evidenced that supplementation with antioxidants should be limited only to cases where oxidative stress has been identified, which is often the case in specific population groups such as postmenopausal women, the elderly, infants, workers exposed to environmental pollutants, and the obese. Meanwhile, diets rich in fruits and vegetables, which are rich sources of antioxidants, are beneficial for one's health and act as anti-aging agents.

\section{Acknowledgment}

The authors acknowledge financial support from the Slovenian Research Agency (research core funding No. P3-0388).

\section{References}

1. Jensen GL, Mirtallo J, Compher C, Dhaliwal R, Forbes A, Grijalba RF, Hardy G, Kondrup J, Labadarios D, Nyulasi I, Castillo Pineda JC, Waitzberg D. Adult starvation and disease-related malnutrition: a proposal for etiology-based diagnosis in the clinical practice setting from the International Consensus Guideline Committee. J Parenter Enteral Nutr. 2010;34(2):156-9.

2. Gillman MW, Cupples LA, Gagnon D, Posner BM, Ellison RC, Castelli WP, Wolf PA. Protective effect of fruits and vegetables on development of stroke in men. JAMA.1995;273 (14):1113-7.

3. Joshipura KJ, Ascherio A, Manson JE, Stampfer MJ, Rimm EB, Speizer FE, Hennekens CH, Spiegelman D, Willett WC. Fruit and vegetable intake in relation to risk of ischemic stroke. JAMA. 1999;282(13):1233-9.

4. Poljšak B, Starc A, Dahmane R. Is the beneficial effect of green tea, wine, olive oil and coffee the consequence of low concentration of $\mathrm{H} 2 \mathrm{O} 2$ formation and its hermetic response? New York: Nova Science Publisher Corp., 2016; p. 165-85.

5. Poljšak B, Glavan U, Dahmane R. Skin cancer, free radicals and antioxidants. Int J Cancer Prev. 2011;4(3):193-217.

6. Potter JD. Cancer prevention: epidemiology and experiment. Cancer Lett. 1997;114(1-2):7-9.

7. Halliwell B. Are polyphenols antioxidants or pro-oxidants? What we learn from cells culture and in vivo studies? Arch Biochem Biophys. 2008;476(2):107-12.

8. Carlisle DL, Pritchard DE, Singh J, Owens BM, Blankenship LJ, Orenstein JM, Patierno SR. Apoptosis and P53 induction in human lung fibroblasts exposed to chromium (VI): effect of ascorbate and tocopherol. Toxicol Sci. 2000;55:60-8.

9. Blumberg J, Block G. The alpha-tocopherol beta-carotene cancer prevention in Finland. Nutr Rev. 1994;52(7):242-5.

10. Khlebnikov AI, Schepetkin IA, Domina NG, Kirpotina LN, Quinn MT. Improved quantitative structure-activity relation- ship models to predict antioxidant activity of flavonoids in chemical, enzymatic, and cellular systems. Bioorg Med Chem. 2007;15:1749-70.

11. Halliwell B, Gutteridge JMC. Free Radicals in Biology and Medicine. $5^{\text {th }}$ edn. Oxford: Clarendon Press, 2015. Available from: https://global.oup.com/academic/product/free-radicalsin-biology-and-medicine.

12. Kancheva VD. Phenolic antioxidants - radical-scavenging and chain breaking activity: a comparative study. Eur J Lipid Sci Technol. 2009;111:1072-89.

13. Pokorny J. Are natural antioxidants better - and safer - than synthetic antioxidants? Eur J Lipid Sci Technol. 2007;109: 629-42.

14. Forman HJ, Davies KJ, Ursini F. How do nutritional antioxidants really work: nucleophilic tone and para-hormesis versus free radical scavenging in vivo. Free Radic Biol Med. 2014; 66:24-35.

15. Fridovich I. Superoxide radical: an endogenous toxicant. Annu Rev Pharmacol Toxicol. 1983;23:239-57.

16. Rahman K. Studies on free radicals, antioxidants and co-factors. Clin Interv Aging. 2007;2:219-36.

17. Turunen M, Olsson J, Dallner G. Metabolism and function of coenzyme Q. Biochim Biophys Acta. 2004;1660:171-99.

18. Jee J, Lim S, Park J, Kim C. Stabilization of all-trans retinol by loading lipophilic antioxidants in solid lipid nanoparticles. Eur J Pharm Biopharm. 2006;3:134-9.

19. Kandar R, Zakova P, Muzakova V. Monitoring of antioxidant properties of uric acid in humans for a consideration measuring of levels of allantoin in plasma by liquid chromatography. Clin Chim Acta. 2006;365:249-56.

20. Barros A, Nunes FM, Gonçalves B, Bennett RN, Silva AP. Effect of cooking on total vitamin $\mathrm{C}$ contents and antioxidant activity of sweet chestnuts (Castanea sativa Mill.). Food Chem. 2011;128:165-72.

21. Burton GW, Traber MG. Vitamin E: antioxidant activity, biokinetics, and bioavailability. Annu Rev Nutr. 1990;10:357-82.

22. Tabassum A, Bristow RG, Venkateswaran V. Ingestion of selenium and other antioxidants during prostate cancer radiotherapy: a good thing? Cancer Treat Rev. 2010;36:230-4.

23. Prasad AS, Bao B, Beck FWJ, Kuck O, Sarkar FH. Antioxidant effect of zinc in humans. Free Radic Biol Med. 2004;37:1182-90.

24. Lee J,Hahm ER, Singh SV.Withaferin A inhibits activation of signal transducer and activator of transcription 3 in human breast cancer cells. Carcinogenesis. 2010;31(11):1991-8.

25. Lastra CA, Villegas I. Resveratrol as an antioxidant and prooxidant agent: mechanisms and clinical implications. Biochem Soc Trans. 2007;35(5):1156-60.

26. Prochazkova D, Boušova I, Wilhelmova N. Antioxidant and prooxidant properties of flavonoids. Fitoterapia. 2011;82: 513-23.

27. Kubo I, Xiao P, Fujita K. Antifungal activity of octyl gallate: structural criteria and mode of action. Bioorg Med Chem Lett. 2011;11:347-50. 
28. Carocho M, Ferreira ICFR. A review on antioxidants, prooxidants and related controversy: Natural natural and synthetic compounds, screening and analysis methodologies and future perspectives. Food Chem Toxicol. 2013;51:15-25.

29. EFSA. Panel on food additives and nutrient sources added to food (ANS); Scientific opinion on the reevaluation of butylated hydroxytoluene BHT (E 321) as a food additive. EFSA J. 2012;10(3):2588.

30. Rahal A, Kumar A, Singh V, Yadav B, Tiwari R, Chakraborty S, Dhama K. Oxidative stress, prooxidants, and antioxidants. Biomed Res Int. 2014;24. Article ID 761264. Available from: https://www.hindawi.com/journals/bmri/2014/761264/.

31. de Bie P, Muller P, Wijmenga C, Klomp LW. Molecular pathogenesis of Wilson and Menkes disease: correlation of mutations with molecular defects and disease phenotypes. J Med Genet. 2007 Nov;44(11):673-88.

32. Cumings JN. The copper and iron content of brain and liver in the normal and in hepato-lenticular degeneration. Brain. 1948 Dec;71(Pt. 4):410-5.

33. Bandmann O, Weiss KH, Kaler SG. Wilson's disease and other neurological copper disorders. Lancet Neurol. 2015 Jan;14 (1):103-13.

34. Herrera E, Jiménez R, Aruoma OI, Hercberg S, Sánchez-García I, Fraga C. Aspects of antioxidant foods and supplements in health and disease. Nutr Rev. 2009;67(1):140-4.

35. Ionescu JG, Merk M, Dowes F. Clinical application of redox potential testing in the blood. Syllabus of $33^{\text {rd }}$ AAEM Annual Meeting, Baltimore, USA. 1998; p. 503-12.

36. Gonzalez MJ, Miranda-Massari JR, Mora EM, Guzman A, Riordan NH, Riordan HD, Casciari JJ, Jackson JA, RomanFranco A. Orthomolecular oncology review: ascorbic acid and cancer 25 years later. Integr Cancer Ther. 2005;4:32-44.

37. Ionescu JG, Novotny JS, Latsch V, Blaurock-Busch A, Eisenmann-Klein M. Increased levels of transition metals in breast cancer tissue. Neuro Endocrinol Lett. 2006;27(1):36-9.

38. Seo MY, Lee SM. Protective effect of low dose of ascorbic acid on hepatobiliary function in hepatic ischemia/reperfusion in rats. J Hepatol. 2002;36(1):72-7.

39. Urbański NK, Beresewicz A. Generation of ${ }^{*} \mathrm{OH}$ initiated by interaction of $\mathrm{Fe} 2+$ and $\mathrm{Cu}+$ with dioxygen; comparison with the Fenton chemistry. Acta Biochim Pol. 2000;47(4):951-62.

40. Asplund KU, Jansson PJ, Lindqvist C, Nordström T. Measurement of ascorbic acid (vitamin $\mathrm{C}$ ) induced hydroxyl radical generation in household drinking water. Free Radic Res. 2002 Dec;36(12):1271-6.

41. Duarte TL, Lunec J. Review: when is an antioxidant not an antioxidant? A review of novel actions and reactions of vitamin C. Free Radic Res. 2005;39:671-86.

42. Podmore ID, Griffiths HR, Herbert KE, Mistry N, Mistry P, Lunec J. Vitamin C exhibits pro-oxidant properties. Nature. 1998 Apr 9;392(6676):559.

43. Poljšak B, Raspor P. The antioxidant and pro-oxidant activity of vitamin $\mathrm{C}$ and trolox in vitro: a comparative study. J Appl Toxicol. 2008;2:183-8.
44. Bjelakovic G, Nikolova D, Gluud L, Simonetti R, Gluud C. Mortality in randomized trials of antioxidant supplements for primary and secondary prevention: systematic review and meta-analysis. JAMA. 2007;8:842-57.

45. Terpinc P, Polak T, Šegatin N, Hanzlowsky A, Ulrih NP, Abramovic H. Antioxidant properties of 4-vinyl derivatives of hydroxycinnamic acids. Food Chem. 2011;128:62-8.

46. Yordi EG, Pérez EM, Matos MJ, Villares EU. Antioxidant and Pro-Oxidant Effects of Polyphenolic Compounds and Structure-Activity Relationship Evidence, Nutrition, Well-Being and Health, Dr. Jaouad Bouayed (Ed.), ISBN: 978-953-510125-3, InTech, Available from: http://www.intechopen.com/ books/nutrition-well-being-and-health/antioxidant-and-prooxidant-effect-ofpolyphenol-compounds-and-structure-activity-relationship-eviden.

47. Dahmane R, Poljšak B. Free radicals and intrinsic skin aging: basic principles. Health Med. 2011;5(6):1647-54.

48. Poljšak B, Pavlović $M$, Adamič M, Dahmane R. Free radicals, antioxidants and intrinsic skin aging. In: First Congress of Montenegro Dermatovenereologists (with international participation), Budva, Montenegro, June 16-19, 2011; p. 36-41.

49. Poljšak B, Glavan U, Dahmane R. Skin cancer, free radicals and antioxidants. Int J Cancer Res Prev. 2011;4(3):193-217.

50. Poljšak B, Dahmane R. Free radicals and extrinsic skin aging. Hindawi Publishing Corporation Dermatology Research and Practice. 2012; Article ID 135206, 4 pages doi: 10.1155/2012/ 135206.

51. Poljšak B, Dahmane R, Godić A. Intrinsic skin aging: the role of oxidative stress. Acta Dermatovenereol Alp Pannonica Adriat. 2012;21(2):33-6.

52. Aruoma OI, Bahorun T, Jen LS. Neuroprotection by bioactive components in medicinal and food plant extracts. Mutat Res. 2003;544:203-15.

53. Aruoma OI, Sun B, Fujii H, Neergheen VS, Bahorun T, Kang KS, Sung MK. Low molecular proanthocyanidin dietary biofactor Oligonol: its modulation of oxidative stress, bioefficacy, neuroprotection, food application and chemoprevention potentials. Biofactors. 2006;27(1-4):245-65.

54. Scofield RH, Kurien BT, Ganick S, McClain MT, Pye Q Jame JA, Schneider RI, Broyles RH, Bachmann M, Hensley K. Modification of lupus-associated $60-\mathrm{kDa}$ Ro protein with the lipid oxidation product 4-hydroxy-2-nonenal increases antigenicity and facilitates epitope spreading. Free Radic Biol Med. 2005;38(6):719-28.

55. Trigwell SM, Radford PM, Page SR, Loweth AC, James RFL, Morgan NG, Todd I. Islet glutamic acid decarboxylase modified by reactive oxygen species is recognized by antibodies from patients with type 1 diabetes mellitus. J Clin Exp Immunol. 2001;126(2):242-9.

56. Beatty S, Koh H, Phil M, Henson D, Boulton M. The role of oxidative stress in the pathogenesis of age-related macular degeneration. Surv Ophthalmol. 2000;45(2):115-34.

57. Babbar N, Gerner EW. Targeting polyamines and inflammation for cancer prevention. Recent Results Cancer Res. 2011; 188:49-64. 
58. Singh U, Jialal I. Oxidative stress and atherosclerosis. Patol Fiziol. 2006;13(3):129-42.

59. Blackburn AC, Coggan M, Shield AJ, Cappello J, Theodoratos A, Murray TP, Rooke M, Larter CZ, Koina ME, Dahlstrom JE, Matthaei KI, Board PG. Glutathione transferase kappa deficiency causes glomerular nephropathy without overt oxidative stress. Lab Invest. 2011;91:1572-83.

60. Ziskoven C, Jäger M, Zilkens C, Bloch W, Brixius K, Krauspe $\mathrm{R}$. Oxidative stress in secondary osteoarthritis: from cartilage destruction to clinical presentation? Orthop Rev. 2010;2(2):e23.

61. Estevez M, Zhuqing Li, Olugbenga P, Soladoye OP, VanHecke T. Health risks of food oxidation. Adv Food Nutr Res. 2018;82:46-73.

62. Filippo CD, Cuzzocrea S, Rossi F, Marfella R, D'Amico M. Oxidative stress as the leading cause of acute myocardial infarction in diabetics. Cardiovasc Drug Rev. 2006;24(2):77-87.

63. Kuršvietienė L, Stanevičienė I, Mongirdienė A, Bernatonienė J. Multiplicity of effects and health benefits of resveratrol. Medicina. 2016;52:148-55.

64. Hercberg S, Galan P, Preziosi P, Bertrais S, Mennen L, Malvy D, Roussel AM, Favier A, Briançon S. The SU.VI.MAX study: a randomised, placebo-controlled trial of the health effects of antioxidant vitamins and minerals. Arch Intern Med. 2004; 164:2335-43.

65. National Institute of Health. NIH State of the Science Conference Statement on Multivitamin/Mineral Supplements and Chronic Disease Prevention. NIH Consens State Sci Statements. 2006;23(2):1-30.

66. Villanueva C, Kross RD. Antioxidant-induced stress. Int J Mol Sci. 2012;13:2091-9.

67. Schafer ZT. Antioxidant and oncogene rescue of metabolic defects caused by loss of matrix attachment. Nature. 2009; 461:109-13.

68. Donato A, Uberoi A, Bailey D, Wray W, Richardson R. Exercise-induced brachial artery vasodilation: effect of antioxidants and exercise training in elderly men. Am J Physiol Heart Circ Physiol. 2010 Feb;298(2):H671-8. doi: 10.1152/ajpheart.00 761.2009 .

69. Richardson R, Donato A, Uberoi A, Wray W, Lawreson L, Nishiyama S, Bailey D. Exercise-induced brachial artery vasodilation: role of free radicals. Am J Physiol Heart Circ Physiol. 2007 Mar;292(3):H1516-22.

70. Gao P, Zhang H, Dinavahi R, Li F, Xiang Y, Raman V, Bhujwalla ZM, Felsher DW, Cheng L, Pevsner J, Lee LA, Semenza GL, Dang CV. HIF-dependent anti-tumorigenic effect of antioxidants in vivo. Cancer Cell. 2007;12:230-8.

71. Narayanan BA. Chemopreventive agents alter global gene expression pattern: predicting their mode of action and targets. Curr Cancer Drug Targets. 2006;6:711-27.

72. Chen D, Guarente L. SIR2: a potential target for calorie restriction mimetics. Trends Mol Med. 2007;13:64-71.

73. Fortalezas S, Tavares L, Pimpăo R, Tyagi M, Pontes V, Alves PM, McDougall G, Stewart D, Ferreira RB, Santos CN. Anti- oxidant properties and neuroprotective capacity of strawberry tree fruit (Arbutus unedo). Nutrients. 2010;2:214-29.

74. Sun AY, Wang Q, Simonyi A, Sun GY. Resveratrol as a therapeutic agent for neurodegenerative diseases. Mol Neurobiol. 2010;41:375-83.

75. Rivière C, Richard T, Quentin L, Krisa S, Mérillon JM, Monti JP. Inhibitory activity of stilbenes on Alzheimer's beta-amyloid fibrils in vitro. Bioorg Med Chem. 2007;15(2):1160-70.

76. Marambaud P, Zhao H, Davies P. Resveratrol promotes clearance of Alzheimer's disease amyloid-beta peptides. J Biol Chem. 2005;280(45):37377-82.

77. Kregel KC, Zhang HJ. An integrated view of oxidative stress in aging: basic mechanisms, functional effects and pathological considerations. Am J Physiol Regul Integr Physiol. 2007;292: 18-36.

78. Blaut M, Schoefer L, Braune A. Transformation of flavonoids by intestinal microorganisms. Int J Vitam Nutr Res. 2003; 73:79-88.

79. Bjelakovic G, Nikolova D, Gluud LL, Simonetti RG, Gluud C. Antioxidant supplements for prevention of mortality in healthy participants and patients with various diseases. Cochrane Database Syst Rev. 2012;14(3):CD007176. Available at: http://onlinelibrary.wiley.com/doi/10.1002/14651858.CD007176.pub2/.

80. Macpherson H, Pipingas A, Pase MP. Multivitamin multimineral supplementation and mortality: a meta-analysis of randomized controlled trials. Am J Clin Nutr. 2013;97(2):437-44.

81. Bjelakovic G, Nikolova D, Gluud C. Antioxidant supplements and mortality. Curr Opin Clin Nutr Metab Care. 2014;17(1): 40-4.

82. Selman C, McLaren JS, Meyer C, Duncan JS, Redman P, Collins AR, Duthie GG, Speakman JR. Life-long vitamin C supplementation in combination with cold exposure does not affect oxidative damage or lifespan in mice, but decreases expression of antioxidant protection genes. Mech Ageing Dev. 2006;127(12):897-904.

83. Childs A, Jacobs C, Kaminski T, Halliwell B, Leeuwenburgh C. Supplementation with vitamin $\mathrm{C}$ and $\mathrm{V}$-acetyl-cysteine increases oxidative stress in humans after an acute muscle injury induced by eccentric exercise. Free Radic Biol Mcd. 2001; 31:745-53.

84. Ströhle A, Wolters M, Hahn A. Food supplements - potential and limits: Part 3. Med Monatsschr Pharm. 2013;36(9):32440. (in German)

85. Rubenowitz E, Molin I, Axelsson G, Rylander R. Magnesium in drinking water in relation to morbidity and mortality from acute myocardial infarction. Epidemiology. 2000;11(4):416-21.

86. Glick JL. Dementias: the role of magnesium deficiency and a hypothesis concerning the pathogenesis of Alzheimer's disease. Med Hypotheses.1990;31(3):211-25.

87. Toba Y, Kajita Y, Masuyama R, Takada Y, Suzuki K, Aoe S. Dietary magnesium supplementation affects bone metabolism and dynamic strength of bone in ovariectomized rats. J Nutr. 2000;130(2):216-20. 
88. Von Schacky C. Omega-3 fatty acids vs. cardiac disease - the contribution of the omega-3 index. Cell Mol Biol (Noisy-legrand). 2010;56(1):93-101.

89. Bougnoux P, Giraudeau B, Couet C. Diet, cancer, and the lipidome. Cancer Epidemiol Biomarkers Prev. 2006;15(3):416-21.

90. Cellini L, Di Campli E, Masulli M, Di Bartolomeo S, Allocati N. Inhibition of Helicobacter pylori by garlic extract (Allium sativum). FEMS Immunol Med Microbiol. 1996;13(4):273-7.

91. World Cancer Research Fund. Food, Nutrition, Physical Activity, and the Prevention of Cancer: a Global Perspective. 2007; Available at: http://www.aicr.org/assets/docs/pdf/reports/Second_Expert_Report.pdf.
92. Stanner S. New thinking about diet and cardiovascular disease. J Fam Health Care. 2006;16(3):71-4.

93. Yilmaz M, Mogulkoc R, Baltaci AK. Effect of three-week zinc and melatonin supplementation on the oxidant-antioxidant system in experimental renal ischemia-reperfusion in rats. Acta Clin Croat. 2015;54:395-401.

94. Harmanci D, Erbayraktar Z, Sayin O, Guner GA. In vitro effects of selenium on human glioblastoma multiforme cell lines: a preliminary study. Acta Clin Croat. 2017;56:48-57, doi: 10.20471/acc.2017.56.01.08.

Sažetak

PROOKSIDACIJSKE AKTIVNOSTI ANTIOKSIDANSA I NJIHOV UTJECAJ NA ZDRAVLJE

\section{R. Sotler, B. Poljšak, R. Dabmane, T. Jukic, D. Pavan Jukic, C. Rotim, P. Trebše i A. Starc}

Ovaj pregledni članak se bavi utjecajem antioksidansa i prooksidansa na zdravlje s naglaskom na tip antioksidansa koji treba uzimati. Medicinski istraživači predlažu da dijeta može biti rješenje za kontrolu kroničnih bolesti kao što su kardiovaskularne komplikacije, hipertenzija, dijabetes melitus i različite vrste raka. U ovom pregledu našli smo znanstvene dokaze da upotreba antioksidansa treba biti ograničena samo na slučajeve gdje je prisutan oksidativni stres. To je često slučaj određenih populacijskih skupina kao što su žene u postmenopauzi, starije osobe, djeca, radnici izloženi onečišćivačima okoliša i pretile osobe. Prije početka bilo koje nadoknade obvezno je izmjeriti oksidativni stres te identificirati i ukloniti moguće izvore slobodnih radikala i posljedično povišeni oksidativni stres.

Ključne riječi: Oksidativni stres; Antioksidansi; Dijeta; Kronična bolest; Prehrana, dodaci; Slobodni radikali 